\title{
Concluding Remarks by Claudio Grossman Guiloff
}

In comparing the thought-provoking papers by professors Keun-Gwan Lee and Hajer Gueldich, we see recurrent themes, such as the strengths of the Commission that have kept it relevant for 70 years. Both offer suggestions for how the Commission can modernize its approach to remain effective in light of the evolving landscape of international relations and the transformative effects of globalization. Their reflections on the Commission's work and their suggestions for the future are very informative. At the same time, the fact that these authors chose to focus on separate, although related, aspects of the Commission forced me to think creatively in responding to their concerns. In performing my own analysis of the Commission after 70 years, I considered many of the issues raised by the professors in their papers, but I also considered some issues that have not, in my opinion, been adequately addressed so far. With due appreciation for the issues highlighted by the professors, I believe it would be great to have their learned opinions about three additional topics: the lack of gender balance on the Commission; the current geopolitical environment amidst declining primacy of the rule of law in international relations and the rise of nationalism; and finally, the "human factor" of international law. We would benefit greatly from receiving the perspectives of these professors on the impact these additional developments have on the work of the Commission.

Both contributors discuss the strengths of the Commission that have allowed it to remain relevant and effective within the field of international law. In my opinion, these strengths can be summarized as follows: (1) the Commission's ability to adapt to meet the changing demands of the international community; (2) the diversity of the Commission; and (3) the Commission's independence. Together, these strengths might prove even more valuable in times of dramatic change, such as now.

The first strength I will address is the Commission's adaptability. In his paper, ${ }^{1}$ Professor Lee quotes Sir Arthur Watt's evaluation of the Commission after 50 years, writing:

The extent to which, at the end of the twentieth century, international law is a more mature system of law and its practitioners can regard their

1 Keun-Gwan Lee, 'Recalibrating the Conception of Codification in the Changing Landscape of International Law' in this Section. 
subject with self-confidence in its worth is very largely due to the contribution made over the first fifty years of its existence by the International Law Commission. ${ }^{2}$

I believe by quoting this statement, Keun-Gwan Lee is implying a question: Has the Commission been as influential over the past 20 years as it was in its first 50 ? I believe the answer is "yes." While I believe the Commission's approach has changed, I believe its impact continues to be just as influential. Changes in the way the Commission approaches its work does not mean the value of its work to the international community is any less apparent. As the Spanish poet Jorge Manrique famously said, "todo tiempo pasado fue mejor," or, "all the past time was better." It is important to consider to what extent our reflections on the past work of the Commission are influenced by nostalgia. Given the tense Cold War environment in which many of the Commission's past achievements were realized, I do not believe the international community saw these achievements the same way we do now. ${ }^{3}$ It seems that only with hindsight these times appear to have been so golden. The Commission's approach has adapted to fit the needs of its clients - States. The international landscape of today is different than it was 5 , or even 20 years ago, and the Commission's approach to its role within that landscape has changed accordingly. While both contributors agree that the historical work of the Commission has tremendously impacted the development of international law and helped stabilize international relations, they also recognize how the Commission's adaptability has enabled it to continue to produce results. In my opinion, when projecting as to the Commission's future, it is important to consider the context within which the Commission's past successes have been achieved, the way the Commission has responded to past challenges, and how the Commission's past experiences have prepared it to face future challenges. We should be careful to view the past successes of the Commission objectively, and in light of their contexts, just as we should be careful not to underestimate the Commission's ability to continue to respond to change.

2 Arthur Watts (ed), The International Law Commission 1949-1998, vol 2 (oup 200o) 20.

3 See e.g. the 'Articles Concerning the Law of the Sea' [1956] II ILC Ybk 254, adopted by the Commission in 1956 and eventually becoming the 1982 United Nations Convention on the Law of the Sea (adopted 10 December 1982, entered into force 16 November 1994, 1833 UNTS 3); the 'Draft articles on consular relations' [1961] II ILC Ybk 92, adopted by the Commission in 1961 and becoming the Vienna Convention on Consular Relations (adopted 24 April 1963, entered into force 19 March 1967, 596 UNTS 261); and the 'Draft articles on the law of treaties' [1966] II ILC Ybk 177, adopted by the Commission in 1966 and converted into the Vienna Convention on the Law of Treaties (adopted 23 May 1969, entered into force 17 January 1980, 1155 UNTS 331). 
In their papers, the contributors detail the emergence of increasingly global concerns that have traditionally been seen as outside the purview of general public international law, including climate change and the growing influence of non-State actors. ${ }^{4}$ Due to these changes, the contributors take note of existing concerns within parts of the international community regarding the Commission's role in developing solutions to these new problems. In his contribution, Keun-Gwan Lee refers to an account of the Commission written by former Commissioner, Donald McRae, which mentioned "a deepseated uncertainty about the contemporary role of the Commission." ${ }^{5}$ While it is important that we continue to evaluate the relevance of all institutions against their designated purpose and their current realities, it is also important to recognize that the existence of challenges or geopolitical tensions in the international community does not necessarily impede the effectiveness of the Commission. In fact, both contributors note the successes of the Commission, even amidst challenges and times of serious tension. ${ }^{6}$ As both professors acknowledge, it is undeniable the Commission contributed to the creation of many foundational building blocks of international law, such as the Vienna Convention on the Law of Treaties, the United Nations' Convention on the Law of the Sea, the Vienna Convention on Diplomatic Relations, the articles on responsibility of states for internationally wrongful acts, ${ }^{7}$ and the Rome Statute of the International Criminal Court. ${ }^{8}$ This body of work is even more noteworthy considering many of these achievements took place during the challenging political times of the Cold War. As Keun-Gwan Lee notes in his paper, the tensions of the Cold War may have, in some respects, contributed to these successes. ${ }^{9}$ He refers to an article by Shabtai Rosenne, which explains how the conventions adopted during the Cold War period based on drafts by the Commission entered into force very quickly, ${ }^{10}$ whereas later instruments, established as the level of tension began to subside, were more slowly adopted by States." In his paper, Keun-Gwan Lee finds value in the ability of the Commission to find alternative ways to respond to international challenges

Hajer Gueldich, 'Challenges of Codification for the International Law Commission in a Changing Landscape of International Law', 289 in this volume, and Lee (n 1) 328. Donald McRae, 'The Interrelationship of Codification and Progressive Development in the Work of the International Law Commission' (2013) 111 JILD 75, 76.

$6 \quad$ Lee (n 1) 331, and Gueldich (n 4) 288.

$7 \quad$ UNGa Res $56 / 83$ (12 December 2001), annex.

8 Adopted 17 July 1998, entered into force 1 July 2002, 2187 UNTS 3.

$9 \quad$ Lee (n 1$) 315$.

10 Shabtai Rosenne, 'Codification Revisited After 5o Years' (1998) 2 MaxPlanckYrbkUNL 10.

11 Ibid. 
when traditional diplomacy is at a stalemate. ${ }^{2}$ Quoting the same article by Rosenne, Keun-Gwan Lee suggests the Commission's ability to open new diplomatic channels is "legal diplomacy at its best."13 The Commission's diplomatic successes during the Cold War may be instructive as the international community evaluates the role of the Commission in today's political climate, and indeed, as the Commission itself works to draw a balance for the future.

The Commission's ability to adapt is also reflected in its approach to codification. Gueldich and Lee addressed the enduring tension concerning the concept of codification and the balance between rigidity and flexibility the Commission has attempted to strike throughout its 70-year history. ${ }^{14} \mathrm{In}$ his paper, Keun-Gwan Lee vividly lays out the tensions within the concept, which have been present within the Commission since its earliest days. He explains how, at the Commission's first meeting, some members saw the goal of codification as creating a code for all of humankind, while others viewed codification as a more modest exercise requiring a topic-oriented approach. ${ }^{15}$ Still, for others, the goal of codification was to promote principles of peaceful coexistence among States with different social and economic systems.

Although "the eventual codification of the entirety of international law" was the goal of many major legal minds at the time of the formation of the Commission, both papers demonstrate the experience of codification within the Commission has diverged from this idea, especially in recent years. ${ }^{16}$ As both contributors noted in their papers, much of the later work products of the Commission, beginning with the articles on responsibility of States for internationally wrongful acts, has come from blending the roles of codification and progressive development to construct normative frameworks of law that States can use to navigate international relations, rather than from stipulating strict rules that leave little or no flexibility for tackling new and varied issues. ${ }^{17}$ Indeed, it is precisely this dual approach taken by the Commission, enabling it to produce soft law instruments addressing specific topics of concern to the international community, which has proved practically useful to States.

\footnotetext{
12 Lee (n 1$) 315$.

13 Rosenne (n 10) 13.

14 Lee (n 1 ) 315, and Gueldich (n 4$) 298$.

15 Lee $(\mathrm{n} 1) 313$.

16 The Commission's change in focus is demonstrated by comparing its early work, such as the articles concerning the law of the sea, the draft articles on consular relations, and the draft articles on the law of treaties, with its later work, such as the articles on responsibility of states for internationally wrongful acts, and its current work topics, only one of which, crimes against humanity, is taking the form of an international convention. Lee (n 1) 322, and Gueldich (n 4) 298.
} 
The Commission's ability to transition its focus from hard law instruments to soft law instruments is further explained in an article written by former member of the Commission Christian Tomuschat, which Keun-Gwan Lee refers to in his paper. ${ }^{18}$ The article is entitled "The International Law Commission - an Outdated Institution?". ${ }^{19}$ Although its title suggests the Commission may have already served its purpose in the progressive development and codification of international law, it is evident, at least in my opinion, that Tomuschat's intention was to show the enduring relevance of the Commission, despite changes in the landscape of international law and international relations since its inception. ${ }^{20}$ While Tomuschat's article does not take for granted that the Commission will always have a place in the international legal system, it demonstrates the Commission is capable of adapting its approaches to meet the current demands of the international community. Tomuschat points to the standalone success of the articles on responsibility of States for internationally wrongful acts as an example of the Commission's intentional move away from focusing primarily on developing conventions to creating soft law instruments. ${ }^{21} \mathrm{He}$ explains the value of the Commission's capacity for adaptation and the power of soft law in international relations, writing:

It would be erroneous to believe that norm setting by framing "principles" or "guidelines" should be valued as only second-rate. Sometimes, codification in the form of a soft-law instrument may prove as effective or even more effective than a treaty which after its launching receives only a hesitant response from the international community. ${ }^{22}$

This example shows the Commission's ability to reform its approach while remaining true to the heart of its purpose, clarifying and balancing international standards. As both papers suggest, international law is not a fixed normative body, it is constantly developing, and we are currently in a moment of transformation. Indeed, due to the Commission's adaptability, we should be cautious in heeding the criticism by some that the Commission does not have a role to play in the current situation of international relations. Perhaps the experience

18 Lee $\left(\begin{array}{ll}n & 1\end{array}\right) 324$.

19 Christian Tomuschat, 'The International Law Commission - An Outdated Institution?' (2006) 49 GYIL 95 .

$20 \quad$ Ibid $95^{-98}$.

21 Ibid.

22 Ibid 104. 
of the Commission shows us we should not so quickly dismiss the relevance of an institution in challenging times.

The second strength of the Commission referred to by both contributors is its diversity. In their papers, both of them refer to the new challenges facing the Commission, the opportunities and added complexities unmasked by globalization, and the increasing heterogeneity within the international community, all of which are transforming and diversifying the landscape of international law. As Gueldich writes in her paper, "[i]t is only natural that the Commission's work would evolve with the legal system it operates in". ${ }^{23}$ She goes on to note that the current international landscape is much different than that in which much of international law developed. On a similar note, Lee refers to recent changes in the structure of the international community and the rise of China, which is making it necessary to consider how such a powerful country with different ideas about the use and structure of the international system will impact the international legal order, and by extension, the work of the Commission. ${ }^{24}$ While the first few hundred years of international law were dominated by a few powerful States with common interests, the international community of today is represented by States with a variety of interests, legal cultures and ideologies. For international law to continue to be relevant, useful and respected by States, it must reflect the changing composition of the international community and the expansion of the community of States. As the contributors imply in their papers, these developments create opportunities for the Commission to take advantage of its diversity in tackling global issues. In fact, the Commission's diversity has been, and likely will remain, critical to its ability to establish widely-accepted and workable frameworks for addressing the current issues of international law. As Christian Tomuschat wrote in the article mentioned previously:

The great advantage of the ILC is that it constitutes a body whose composition establishes a fair balance between all of the different regions of the world, and whose members have learned to cooperate with one another in a peaceful and constructive manner. Thus, together with the ICJ, the ILC guarantees that international law remains an effective instrument determining the conduct of all relevant actors in the international field. ${ }^{25}$

\footnotetext{
23 Gueldich (n 4) 288.

24 Lee $\left(\begin{array}{ll}n_{1} & 3_{2} 8 .\end{array}\right.$

25 Tomuschat (n 19) 105.
} 
Social science calls the practice of bringing together different ideas to create more innovative solutions the "edge effect." The term was co-opted from ecologists who discovered the boundaries between different ecosystems boost higher levels of biodiversity because they share qualities of both neighboring systems. ${ }^{26}$ These "edges" often contain species not found in the individual systems. ${ }^{27}$ In the social science realm, scientists have similarly found that a diversity of viewpoints breeds more creative solutions. ${ }^{28}$ The diversity of the Commission can also be viewed as creating a sort of edge effect, where the bringing together of legal experts from diverse legal traditions can lead to more creative, collective solutions to global problems. Additionally, as Hajer Gueldich points out, this type of cooperative approach is necessary because the problems facing the global community today cannot be solved by States acting in isolation. ${ }^{29}$ However, the diversity of the Commission could be even stronger, namely in respect to gender equality. I will address this concern later in my remarks.

The final common strength referred to by the contributors is the Commission's independence. The Commission's diversity and adaptability reinforce its crucial role as an independent body during times, such as now, where the political environment shows dramatic change. The Commission has demonstrated a capacity that is not immediately vulnerable to changing and challenging political climates. The Commission's independence does not mean it is disconnected from political realities. Rather, its independence allows it to see past short-sighted political expediency to find enduring, equitable solutions to international issues. In his paper, Keun-Gwan Lee acknowledges that the Commission's position as a subsidiary organ of the General Assembly links it to the political realities of States without handicapping its ability to find solutions. ${ }^{30}$ From this point of view, we can see the Commission represents the legal interests of the larger international community, and has, due to the nature of its mandate regarding codification and progressive development of international law, created a space for autonomy and independent action in its quest to promote the role of international law in international relations.

In times like the present, it might be the case that the value of the Commission's independence is especially noticeable. That being said, the competence

26 National Public Radio, 'The Edge Effect' (Hidden Brain 2018) <https://www.npr.org/2018/ o7/02/625426015/the-edge-effect>.

27 Ibid.

28 Ibid.

29 Gueldich (n 4) 298.

$30 \quad$ Lee $\left(\begin{array}{ll}n & 1\end{array}\right) 329$. 
for international law is vested with States as the primary subjects of international law. Therefore, for the Commission's work to be effective, it cannot ignore this basic reality and must remain attuned to the political climate in which it operates. It does not advance the position or utility of international law to exaggerate its role in international relations, which are also subject to political, military, and economic concerns. However, international law is critical to harmonizing States' interests, including safeguarding the stability and security of individual States, ensuring peace among States, stabilizing international relations, and channeling demands for adaptation and change.

Considering the current times of change, both papers also refer to the need for the Commission to modernize both its topic selection process and its working methods. While acknowledging existing criticism, by some, of the Commission's choice to study more divisive topics, both papers also acknowledge the importance of the Commission's attention to these issues. The idea that the Commission should not focus on divisive issues has been discussed throughout the Commission's existence. In the papers discussing the Commission's fiftieth anniversary, similar criticisms to those we hear today were lodged in response to the Commission's consideration of topics related to protection of the environment, human rights, and self-determination. ${ }^{31}$

While I believe the Commission must stay apprised of the political realities of the world it operates in, so its work can be useful to States, I also believe the Commission would be neglecting its role in the progressive development and codification of international law if it ignored any topic that might be perceived as problematic. Most issues facing the international community today are in some way controversial. As Hajer Gueldich notes in her paper, globalization is shaping the international order and raising new global issues that cannot be tackled by individual States. ${ }^{32}$ Similarly, Keun-Gwan Lee suggests the Commission transition its focus from inter-State topics to global and transnational ones that have more relevance to States today. ${ }^{33}$ I agree with these suggestions; part of the Commission's endeavour to remain relevant should involve modernizing its selection of topics. I also believe the Commission should not ignore the role it can play by employing the powerful tradition of international law to contribute to the development of normative concepts acceptable to the international community. The Commission should not shy away from

31 Vaughan Lowe, 'Presentation by Mr. Vaughan Lowe' in United Nations (ed), The International Law Commission Fifty Years Later: an Evaluation (United Nations 200o) 134-135.

32 Gueldich (n 4) 289.

33 Lee (n 1$) 33$ o. 
topics that have a tremendous impact on States and the international community as a whole, such as rights and protections for refugees and internally displaced persons; peace, security, and lawful uses of force; protection of the environment; data security and privacy; and general principles relevant to the conduct of international economic relations. Many of these topic suggestions were also noted in the papers presented by the professors. I believe the writings of the preeminent international jurist, Rosalyn Higgins, regarding the political aspects of law, correctly illustrate the tension the Commission faces in deciding whether to take on controversial, but critically important topics. As Judge Higgins explains, for some, the judicial process is neutral; it is a process of applying objective norms. ${ }^{34}$ For others, the judicial process involves values and political consequences. ${ }^{35}$ Even if one accepts the non-positive approach to international law, it must be acknowledged that the lines between law and politics are both blurred and interconnected. Politics create a domain in which law can develop. In my opinion, the Commission is strategically positioned to operate within that domain.

In addition to suggesting ways the Commission can modernize its topic selection, both contributors also suggest ways the Commission can modernize its working methods to include new perspectives and ideas. They suggest the Commission work more closely with other international actors and institutions. Keun-Gwan Lee suggests prioritizing the Commission's work and taking into account codification efforts done by other actors - even if they may not have the same legitimacy as the Commission - to ensure the efficient use of the Commission's resources. ${ }^{36}$ On the other hand, Hajer Gueldich notes trends in international law towards granting rights and imposing obligations on non-State actors, and therefore advocates for increased cooperation with civil society, NGOs, and technical experts. ${ }^{37}$ I very much agree with these suggestions, and believe that by considering the work done by others, we can "open the windows" of the Commission. The role of non-State actors in international law is growing - whether the issue be economic rights, environmental protection, or armed conflict. While States remain the primary subjects and creators of international law, the political, social, and economic realities of the world require enriching the work of the Commission by considering the concerns and opinions of other international actors. In my opinion, both

34 Rosalyn Higgins, Problems and Process: International Law and How We Use It (oup 1994) 2-6.

35 Ibid.

36 Lee (n 1$)$ 324-330.

37 Gueldich (n 4) 295-296 and 298. 
papers also suggest that by considering the full spectrum of international actors, the Commission would not in any way be questioning the relevance of States. Instead, considering the opinions and actions of these other actors, and taking into account current political realities, should be seen as a way to enrich the decision making process, and accordingly, the outcomes of the Commission's work.

I will move now to some additional concerns I feel have been unfortunately left out of our discussion so far: the lack of gender balance on the Commission; the decline in support for multilateralism coupled with the rise of nationalism; and the significance of the "human factor" within international law and the Commission's work.

As many here know, in the past 70 years, there have only been seven women elected to the Commission. This figure is extremely concerning, and lags far behind the advancements in gender equality achieved in other areas of international law, international relations, and politics generally. In fact, women represent only 3 per cent of the Commission's membership over its entire 70year history. If the Commission is going to represent "the main forms of civilization and ... the principal legal systems of the world," as mandated in article 8 of its statute, ${ }^{38}$ and truly reflect the international community of States and citizens it serves, States from all regions of the world will need to nominate more women to the Commission and the General Assembly will need to elect more women to the Commission. This likely also means States will need to increase opportunities for women within international law. Judging from the attendance of the panel discussion in Geneva, it is obvious that there is no lack of interest or ability among women in this field. Achieving a more balanced and diverse Commission will help ensure that the Commission's work remains relevant and pertinent to the international community. Gender equality on the Commission should be viewed as equally important to other forms of diversity within the Commission. Gender diversity would contribute to the "catalyst of reason,"39 created by the joining of diverse perspectives, just as the Commission's diversity of legal cultures and legal backgrounds does. As almost every speaker at our commemoration in New York expressed, we must do more to achieve gender equality on the Commission, and I believe this concern would have deserved more attention from the speakers at our commemoration events in Geneva.

38 Statute of the ILC, UNGA Res 174(II) (21 November 1947) as amended by UNGA Res 485(V) (12 December 1950); Unga Res 984(x) (3 December 1955); UNGa Res 985(x) (3 December 1955) and UNGA Res 36/39 (18 November 1981).

Tomuschat (n 19) 81. 
Turning now to my second concern. A few years ago, it seemed the trends of globalization would strengthen international law; however, it is now necessary to revise our optimism. As the President of the International Court of Justice, Abdulqawi Yusuf, stated in his keynote address, the Commission must play a role in responding to threats to the integrity of the multilateral system and continue to promote multilateralism and inclusivity. ${ }^{40}$ Responding to these threats is especially important when the role of law itself is at stake. Accordingly, I believe the Commission must pay attention to the current rule of law crisis facing the international community. In recent years, some States have questioned the core institutions and norms at the centre of the international community, as well as the importance of a rule-based order to international relations, including some States that were instrumental in the construction of these institutions and norms. Some States have instead turned to different forms of populism and nationalism, seeking to free themselves as much as possible from the normal constraints on the use of power in international relations. The rise of populism and nationalism, the erosion of settled law prohibiting the use of force in resolving disputes, and the general decline in the appreciation and observance of international law, cannot be ignored. Just as when the Commission was established 70 years ago, our world is facing challenges no State can address or solve alone. International cooperation on these issues is imperative. Political bodies, such as the Security Council, have failed to act in even the most appalling humanitarian circumstances, both historically, as in the cases of Kosovo and Rwanda, and currently, as in the cases of Syria and Myanmar. Similarly, the European Union has so far failed to adequately address the threats of populism and judicial corruption in certain member States, and these ideologies continue to spread, both in Europe and in other parts of the world, including the United States. Political scientist Joseph Nye has explained the Trump administration's approach to international affairs saying, in effect, that the administration has replaced the nation's former soft power, cooperative approach, with a hard power approach, focused on coercion and military might. ${ }^{41}$ Hopefully, the international community can find ways to utilize legal institutions, like the Commission, to address these issues through international law and avoid the devastating catalytic events that have historically been required to motivate united action.

40 See the keynote address by Abdulqawi Yusuf in Section 9 of this volume.

41 Joseph S Nye, 'Donald Trump and the Decline of US Soft Power' Project Syndicate (6 February 2018) < https://www.project-syndicate.org/commentary/trump-american-softpower-decline-by-joseph-s--nye-2018-o2>. 
Needless to say, these are concerning political trends that could have serious impacts on the international community, and on the concept of international law itself, which purports to establish agreed norms applicable to all. Even while we have seen some major players in the multilateral system retreat from their historically prominent positions, we have seen increases in activism by other States as well as citizen and local level engagement across many areas. We have seen movements around the globe mobilizing for change. For example, the Women's Marches around the World in 2017 and 2018, ${ }^{42}$ and United States' corporations, states, and cities pledging to do their part to meet greenhouse gas emission reduction commitments under the Paris Agreement, ${ }^{43}$ despite the Trump administration initiating a United States exit from the agreement. ${ }^{44} \mathrm{We}$ have seen local and city governments, businesses, and citizens innovating new solutions to local and global issues. While these developments cannot be exaggerated, they also cannot be ignored, as they have the ability to impact international relations. The Italians have an expression "chiaroscuro" - clear and dark at the same time - and current times, with all their complexity, show us the validity of this apparently contradictory concept. The Commission has a role to play in preserving and advancing the international commitment to a rule-based order that ensures and protects the rights of all States and individuals equally.

As both contributors suggest, these international developments leave a space for the Commission, as a body of independent experts, in touch with political realities, but not locked into specific and narrow political options, to objectively promote the development of international law for the benefit of humankind. While reading the papers, I thought of the value of the process, and the value of the effort itself. To quote the famous author, Miguel de Cervantes, in the crucial work of Spanish literature, Don Quixote, "mejor el camino

42 The 2017 Women's Marches in the US were likely the largest single day demonstration in US history, with as many as 5.2 million people participating in the US and over 300 ,ooo people participating in at least 261 marches abroad. See Erica Chenoweth and Jeremy Pressman, "This is What we Learned by Counting the Women's Marches" The Washington Post (Washington, 7 February 2017) < https://www.washingtonpost.com/news/monkeycage/wp/2017/o2/o7/this-is-what-we-learned-by-counting-the-womens-marches/?noredirect=on\&utm_term=.1a4551efo971>.

43 Adopted 12 December 2015, entered into force 4 November 2016, UNTS registration no 54113 .

44 See e.g. the "We Are Still In" coalition is an organization made up of over 1,ooo United States' CEO s, governors, and mayors pledging commitment to the Paris Agreement on climate change. See Mythili Sampathkumar, 'US Cities and Companies Declare "We Are Still in" Paris Agreement Despite Trump' The Independent (London, 10 November 2017) <https://www.independent.co.uk/news/paris-agreement-trump-us-cities-still-indefiance-coalition-a8047086.html>. 
que la posada" or "better the road than the inn." There is value in the process of preserving a way of thinking, a methodology. There is value in keeping and developing a space for legal reasoning, a space for discussion based on the common language of international law. We need to talk about these serious issues. We need to create space and keep space for strengthening the validity of the rule of law. In my opinion, the Commission has a major role to play in maintaining and developing the rule-based order of international relations, and that role is critically important in the current political environment.

This common narrative of international law has expanded due to interdependence, and as both professors have written, we cannot solve problems facing humankind solely through actions by individual States. As stated by Judge Álvarez in his dissenting opinion in the International Court of Justice advisory opinion on the Effect of Awards of Compensation made by the United Nations Administrative Tribunal:

The social character of the international law of today is a result of the new regime of inter-dependence which has emerged and which tends to replace the traditional individualistic regime. Having regard to this social character, what may be called the new international law is particularly concerned with the maintenance of peace and the development of confidence and cooperation between States; it assigns an important place to the general interest and condemns abus du droit; it also has a new aim: the well-being of the individual and of society. ${ }^{45}$

Finally, I believe one other important topic has been absent here: the "human factor." Much of what happens in the world depends on human behavior, on leadership, on how things happen. When he was asked what we should expect in the 21st-century, Nobel Prize winning author, Gabriel Garcia Marquez, said we should not expect anything just because we are entering a new century. The most relevant things that have happened to us are the result of individuals imagining them before they became reality. This was, for example, the case with Beethoven's ninth symphony and heart transplants. These achievements began in the minds of their creators; they were imagined before they happened.

As we face the conditions of our time, we should remember that we are not mere spectators, but rather subjects in these events; and, in order to promote the change we wish to see, we need to imagine our contribution to the development of international law and translate what we imagine into action. 
The United Nations - 9789004434271

Downloaded from Brill.come4/26/2023 11:15:39AM via free access 